\title{
PENGARUH SISTEM PELAYANAN PAJAK DAN \\ KEPATUHAN WAJIB PAJAK ORANG PRIBADI TERHADAP \\ PENERAPAN SELF ASSESSMENT SYSTEM \\ DI KANTOR PELAYANAN PAJAK PRATAMA BANTUL
}

\author{
Uum Helmina Chaerunisak \\ Suyanto* \\ Program Studi Akuntansi, Fakultas Ekonomi \\ Universitas Sarjanawiyata Tamansiswa \\ *iyantsuyanto@gmail.com
}

\begin{abstract}
This study was conducted to examine the effect of the tax system variables and individual tax compliance on the implementation of self assessment system in KPP Pratama Bantul. This study uses the dependent variable is self assessment system and the indepen dent variable is the tax system, an individual taxpayer compliance are listed in the KPP Pratama Bantul. The sampling technique used is random sampling of individual taxpayers in the region of Bantul and individuals who have a NPWP. Data collection procedures using a questionnaire which was distributed to be filled by an individual taxpayer. The analysis technique used is multiple regression with SPSS 16.0 tools.

Based on the results of the analysis indicate that the variable tax system and compliance services an individual taxpayer simul tan proved significant effect on the implementation of self assessment system. Predictive ability of the three variables on self assessment system shows the independent variables can explain the variation in the dependent variable of $34.8 \%$ and the rest is explained by other variables.
\end{abstract}

Keywords: system of service tax, individual tax compliance, and self assessment system .

\section{PENDAHULUAN}

Pajak merupakan sumber penerimaan negara yang memiliki peran penting dari waktu ke waktu. Mengingat pentingnya peranan pajak, maka pemerintah dalam hal ini Direktorat Jenderal Pajak telah melakukan berbagai upaya untuk memaksimalkan penerimaan pajak. Salah satu upaya yang dilakukan adalah melalui reformasi peraturan perundang-undangan di bidang perpajakan dengan diberlakukannya self assessment system dalam pemungutan pajak sejak tahun fiskal 1984 (Santi, 2011). Self assessment system merupakan sistem yang memberikan kepercayaan penuh kepada wajib pajak untuk menghitung, memperhitungkan, menyetor, dan melaporkan ke Kantor Pelayanan Pajak seluruh pajak yang menjadi kewajibannya. Kepatuhan wajib pajak sangatlah penting dalam menghitung dengan jujur pajak terutang dan menyetor serta melaporkannya tepat waktu.

Di Kantor Pelayanan Pajak melayani wajib pajak dengan tujuan untuk memberikan kenyamanan, keamanan, dan kepastian bagi wajib pajak dalam memenuhi kewajiban dan haknya di bidang perpajakan.Sosialisasi tentang mengapa, bagaimana, dimana, kapan, dan apa perpajakan itu selalu dilakukan sehingga wajib pajak dapat memahami dan mampu memenuhi kewajiban dan haknya sesuai dengan Undang-Undang Perpajakan yang berlaku. Keamanan juga sangat diperlukan untuk mengawasi ketiga fungsi agar berjalan dengan baik.

Pelayanan pajak yang baik diharapkan dapat membawa pengaruh baik bagi wajib pajak untuk memenuhi kewajibannya membayar pajak. Seperti dalam penelitian 
yang dilakukan Suyatmin (2010) disebutkan bahwa untuk meningkatkan kepatuhan Wajib Pajak dalam memenuhi kewajiban perpajakannya, kualitas pelayanan pajak harus ditingkatkan oleh aparat pajak.

Pelayanan fiskus yang baik akan memberikan kenyamanan bagi Wajib Pajak - Berdasarkan uraian di atas, maka penelitian ini mengangkat topik tentang sistem pemungutan pajak dengan judul "Pengaruh Sistem Pelayanan Pajak dan Kepatuhan Wajib Pajak Orang Pribadi Terhadap Penerapan Self Assesment System

\section{TINJAUAN PUSTAKA Pajak}

Pengertian pajak menurut UndangUndang Perpajakan yaitu iuran rakyat kepada negara berdasarkan undang-undang dengan tidak mendapat jasa timbal yang langsung dapat ditunjuk dan digunakan untuk membiayai pengeluaran umum dan pembangunan.

Pajak mempunyai peranan penting dalam kehidupan bernegara, khususnya di dalam pelaksanaan pembangunan karena pajak merupakan sumber pendapatan negara untuk membiayai semua pengeluaran termasuk pengeluaran pembangunan. Berdasarkan hal di atas maka pajak mempunyai beberapa fungsi. Menurut Resmi (2007), fungsi pajak adalah sebagai berikut:

1. Fungsi Budgetair (Keuangan Negara)

2. Fungsi Regulered (Mengatur)

Menurut Resmi (2007), terdapat berbagai jenis pajak, yaitu: (a) Berdasarkan Golongan x Pajak Langsung x Pajak Tidak Langsung; (b) Berdasarkan Sifat x Pajak Subyektif x Pajak Obyektif; (c) Berdasarkan Lembaga Pemungut $x$ Pajak Pusat atau Pajak Negara x Pajak Daerah.

Subjek pajak merupakan subjek yang dikenakan pajak sesuai yang diatur oleh Undang-undang yang berlaku (Waluyo, 2008). Subjek pemungutan pajak menurut Waluyo (2008) sebagai berikut:

1. Orang pribadi.

2. Warisan yang belum terbagi
3. Badan

4. Bentuk usaha tetap

Objek Pajak merupakan objek pengenaan pajak dan dijadikan dasar untuk menghitung pajak terutang (Waluyo, 2008). Objek pemungutan pajak adalah

a. penghasilan;

b. laba usaha;

c. hadiah dari undian atau pekerjaan;

d. keuntungan karena penjualan atau karena pengalihan harta;

e. deviden.

Resmi (2007) menyatakan bahwa dalam pemungutan pajak dikenal beberapa sistem pemungutan pajak, yaitu antara lain:

1. Official Assessment System merupakan suatu sistem pemungutan pajak yang memberi kewenangan aparatur perpajakan untuk menentukan sendiri jumlah pajak yang terutang setiap tahunnya sesuai dengan ketentuan undang-undang perpajakan yang berlaku.

2. Self Assessment System merupakan suatu sistem pemungutan pajak yang memberi wewenang Wajib Pajak untuk menentukan sendiri jumlah pajak yang terutang setiap tahunnya sesuai dengan ketentuan undang-undang perpajakan yang berlaku.

3. With Holding System merupakan suatu sistem pemungutan pajak yang memberi wewenang kepada pihak ketiga yang ditunjuk untuk menentukan besarnya pajak yang terutang oleh Wajib Pajak sesuai dengan ketentuan undang-undang perpajakan yang berlaku.

\section{Sistem Pelayanan Pajak}

Menurut Boediono (2003) pelayanan umum harus dilaksanakan dalam suatu rangkaian kegiatan terpadu yang bersifat: sederhana, terbuka, lancar, tepat, lengkap, wajar dan terjangkau. Salah satu bentuk pelayanan publik adalah pelayanan perpajakan terhadap wajib pajak. Sedangkan pengertian pelayanan menurut kamus besar bahasa Indonesia, adalah a) perihal atau cara melayani; b) servis dan jasa; c) kemudahan yang diberikan sehubungan dengan jual beli barang tau jasa. 
Selain itu, Sofyan (2003) mengemukakan bahwa sistem penetapan pajak harus mencerminkan adanya kepastian hukum, keadilan dan kemudahan agar tanggung jawab Wajib Pajak dalam memenuhi kewajiban perpajakan dapat dipenuhi sesuai peraturan perundangundangan perpajakan. Selain itu juga Wajib Pajak tidak boleh diperlakukan sebagai obyek, tetapi sebagai subyek yang harus dibina agar bersedia, mampu dan sadar melaksanakan kewajiban perpajakan. Berdasarkan uraian di atas, maka peneliti dapat menentukan hipotesis dalam penelitian ini sebagai berikut:

H1: sistem pelayanan pajak berpengaruh positif terhadap penerapan Self Assessment System.

\section{Kepatuhan Wajib Pajak}

Pengertian kepatuhan menurut kamus bahasa Indonesia berarti tunduk atau patuh pada ajaran atau aturan. Sedangkan menurut Nurmantu (2006) dalam Widjaya (2011), kepatuhan perpajakan didefinisikan sebagai suatu keadaan dimana Wajib Pajak memenuhi semua kewajiban perpajakan dan melaksanakan hak perpajakannya.Menurut Ismawan (2001) agar tercapainya kepatuhan yang sukarela terdapat beberapa faktor yaitu pelayanan yang baik, prosedur yang sederhana dan mudah serta pemantauan kepatuhan dan verifikasi yang efektif.

Dari pengertian tersebut maka pastinya pelayanan terhadap masyarakat dapat mempengaruhi kepatuhan wajib pajak orang pribadi terhadap instansi yang terkait dalam hak ini adalah KPP. Di dukung juga oleh hasil penelitian Budileksama (2001) berdasarkan self assessment system wajib pajak menghitung, membayar, dan melaporkan kewajiban perpajakannya. Sebagai konsekuensinya, DJP melakukan pemeriksaan dengan tujuan utama untuk menguji kepatuhan pemenuhan kewajiban perpajakan dalam rangka meningkatkan kepatuhan wajib pajak.

Berdasarkan uraian di atas, maka peneliti dapat menentukan hipotesis dalam penelitian ini sebagai berikut:

$\mathrm{H} 2$ : kepatuhan wajib pajak berpengaruh positif terhadap penerapan Self Assessment System

\section{Self Assessment System}

Self assessment system adalah pemungutan pajak yang memberi wewenang, kepercayaan, tanggung jawab kepada wajib pajak untuk menghitung, memperhitungkan, membayar dan melaporkan sendiri besarnya pajak yang harus dibayar (Waluyo dkk, 2003). Kesit (2001) menyatakan bahwa berlakunya self assessment system pemungutan pajak menuntut wajib pajak untuk lebih mandiri dalam pengelolaan administrasi perpajakannya. Hal ini merupakan bentuk refleksi dari azas pemungutan pajak yang dianut oleh pemerintah yaitu azas pelimpahan kepercayaan sepenuhnya kepada masyarakat.

Kelebihan self assessment system ini adalah Wajib Pajak diberi kepercayaan oleh pemerintah (Fiskus) untuk menghitung, membayar, dan melaporkan sendiri pajak yang terutang sesuai dengan ketentuan perpajakan yang berlaku. Menurut

Sadhani (2004), kelemahan self assessment system yang memberikan kepercayaan pada Wajib Pajak untuk menghitung, menyetorkan dan melaporkan sendiri pajak terutang, dalam praktiknya sulit berjalan sesuai dengan yang diharapkan atau bahkan disalahgunakan system belum bisa diterapkan oleh Wajib pajak Orang Pribadi terutama pemilik kost, karena mereka sering kali tidak melaporkan atau mencantumkan Pajak Penghasilannya di SPT. Hal ini dilakukan oleh Wajib Pajak pemilik rumah kost karena rendahnya tingkat kejujuran Wajib

Pajak 


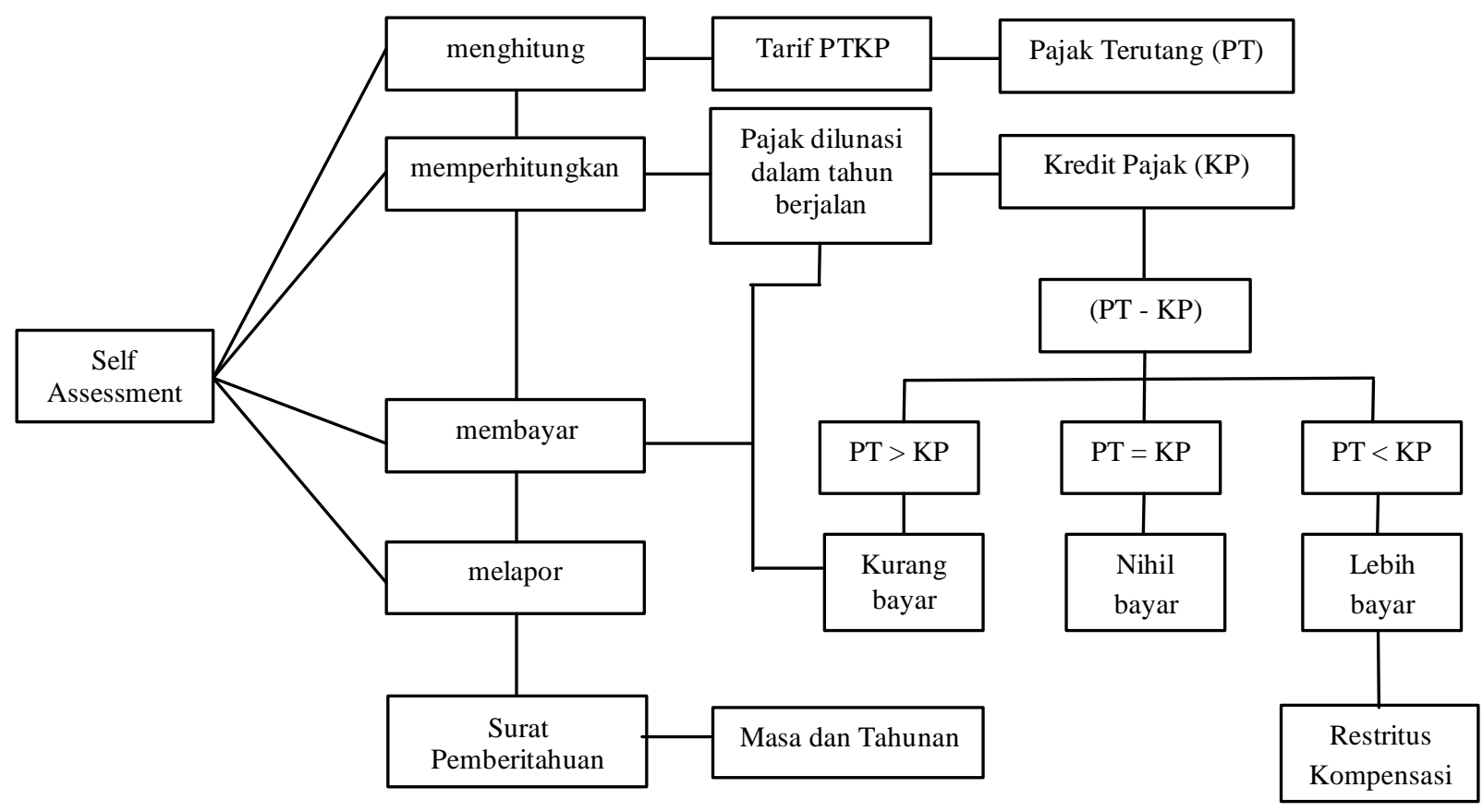

Penelitian Novianti (1997) menyimpulkan bahwa pelaksanaan self assessment dan kurangnya pengetahuan Wajib Pajak terhadap ketentuan perpajakan. Berdasarkan uraian di atas, maka peneliti dapat menentukan hipotesis dalam penelitian ini sebagai berikut:

H3: Sistem pelayanan pajak dan kepatuhan wajib pajak orang pribadi berpengaruh positif terhadap penerapan Self Asseessment System.

\section{Kerangka Konseptual}

Kerangka konseptual dalam penelitian ini dapat digambarkan pada gambar di bawah ini:

\section{Gambar 1}

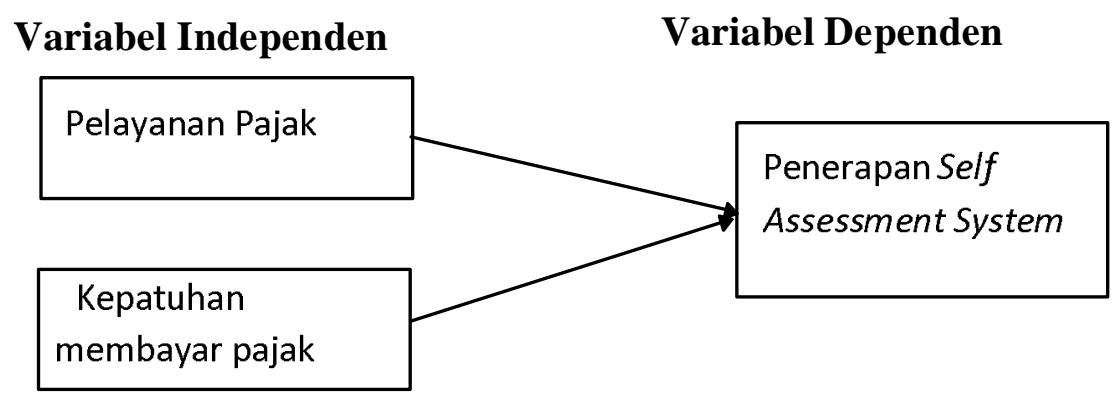

\section{Kerangka Konseptual}

Pada peneltian ini, kerangka konseptual menjelaskan bahwa dengan berlakunya Self Assessment System, maka Wajib Pajak dituntut untuk menghitung, menyetorkan dan melaporkan sendiri pajak terutang yang merupakan kewajiban setiap
Wajib Pajak. Dan pemerintah dalam hal ini aparat pajak hanya bertugas melayani, mengawasi dan melakukan penyuluhan untuk mengetahui kepatuhan Wajib Pajak.Untuk menyederhanakan alat pemikiran tersebut maka kerangka pemikiran ini dapat digambarkan sebagaimana di atas. 


\section{METODE PENELITIAN}

\section{SIFAT PENELITIAN}

Penelitian ini merupakan penelitian kuantitatif. Data yang digunakan dalam penelitian ini yaitu data primer. Pengumpulan data ini dilakukan dengan menyebarkan kuisioner sehingga mendapatkan informasi mengenai persepsi wajib pajak tentang sistem pelayanan, kepatuhan wajib pajak, dan penerapan self assessment system. Penelitian ini mengukur tentang pengaruh sistem pelayanan pajak dan kepatuhan wajib pajak orang pribadi terhadap penerapan self assessment system di Kantor Pelayanan Pajak Pratama Bantul.

\section{VARIABEL PENELITIAN}

1. Variabel dependen (Y) : Self assessment system

2. Variabel independen $x$ Sistem Pelayanan Pajak (X1) x Kepatuhan Wajib Pajak (X2)

\section{DEFINISI OPERASIONAL}

\section{Sistem Pelayanan Pajak (X1)}

Pada penelitian ini, variabel ini diukur dengan kuisioner skala likert 5 point untuk 9 pertanyaan. Berikut ini ringkasan definisi operasional sistem pelayanan pajak.

Tabel 1

Definisi Operasional Sistem Pelayanan Pajak

\begin{tabular}{|c|c|c|c|}
\hline Variabel & Definisi Operasional & Indikator & Skala \\
\hline $\begin{array}{l}\text { Sistem } \\
\text { pelayanan } \\
\text { pajak (X1) }\end{array}$ & $\begin{array}{l}\text { pelayanan umum harus } \\
\text { dilaksanakan dalam suatu } \\
\text { rangkaian kegiatan terpadu } \\
\text { yang bersifat: sederhana, } \\
\text { terbuka, lancar, tepat, } \\
\text { lengkap, wajar dan } \\
\text { terjangkau. Salah satu } \\
\text { bentuk pelayanan publik } \\
\text { adalah pelayanan } \\
\text { perpajakan terhadap wajib } \\
\text { pajak } \\
\text { (Boediono, 2003) }\end{array}$ & $\begin{array}{l}\text { 1. Fiskus tepat waktu melayani wajib } \\
\text { pajak dalam waktu yang } \\
\text { ditentukan. } \\
\text { 2. Produksi pelayanan publik diterima } \\
\text { dengan benar, tepat, dan sah. } \\
\text { 3. Wajib pajak tidak merasa aman } \\
\text { dalam proses dan pelayanan publik. } \\
\text { 4. Kelengkapan sarana dan prasarana } \\
\text { tersedianya sarana kerja peralatan } \\
\text { kerja dan pendukung lainnya } \\
\text { yang memadai termasuk } \\
\text { penyediaan sarana teknologi } \\
\text { telekomunikasi dan informatika } \\
\text { (telematika). dan } \\
\text { Kemudahan akses Tempat dan } \\
\text { lokasi serta sarana pelayanan yang } \\
\text { memadai, mudah dijangkau oleh } \\
\text { masyarakat, dan dapat } \\
\text { memanfaatkan teknologi } \\
\text { telematika. } \\
\text { Kedisiplinan, kesopanan, dan } \\
\text { keramahan Pemberi pelayanan } \\
\text { harus bersikap disiplin, sopan, dan } \\
\text { santun, ramah serta memberikan } \\
\text { pelayanan yang ikhlasWajib pajak } \\
\text { tidak mempunyai hak dalam } \\
\text { membetulkan SPT. } \\
\text { Kenyamanan hingkungan } \\
\text { pelayanan harus tertib, disediakan } \\
\text { ruang tunggu yang nyaman, bersih, } \\
\text { rapi, lingkungan yang indah, sehat }\end{array}$ & Ordinal \\
\hline
\end{tabular}


serta dilengkapi dengan fasilitas

pendukung pelayanan, seperti

parkir, toilet, tempat ibadah, dan lain-lain

8. Kompetensi pelayanan pajak sangat tinggi.

9. Fiskus memberikan perhatian pada wajib pajak.

Pada penelitian ini, variabel ini diukur dengan kuisioner skala likert 5 point untuk 14 pertanyaan. Berikut ini ringkasan definisi operasional kepatuhan wajib pajak orang pribadi.

Tabel 2

Definisi Operasional Kepatuhan Wajib Pajak Orang Pribadi

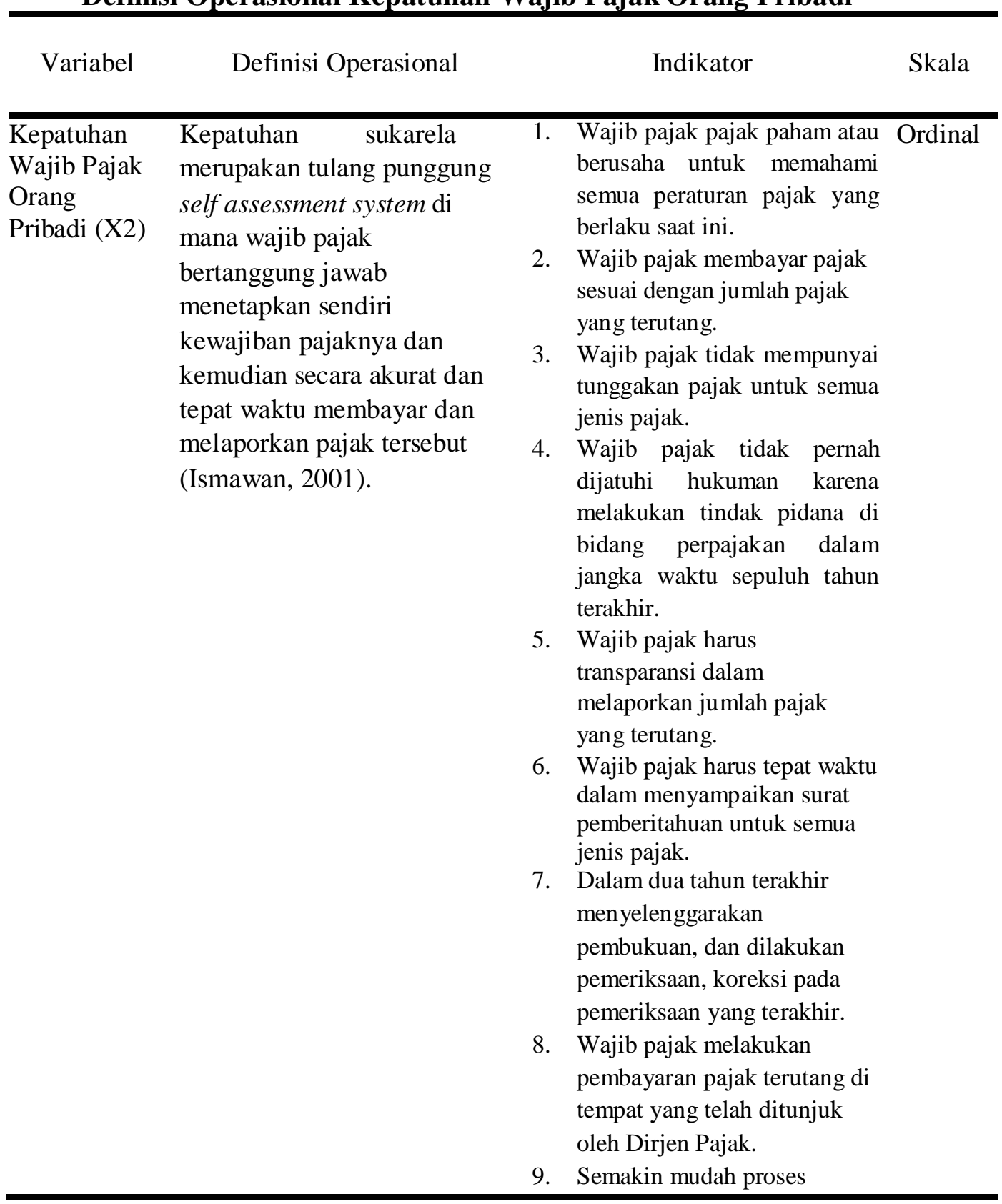


pembayaran pajak, semakin

tinggi tingkat kesadaran

seseorang dalam membayar pajaknya.

10. Wajib pajak menggunakan tarif pajak yang sesuai dengan peraturan pajak yang berlaku.

11. Pemberian informasi tentang pajak sangat penting hal ini dikarenakan banyak masyarakat yang belum mengetahui fungsi dari pajak tersebut.

12. Dengan adanya penyuluhan oleh Dirjen Pajak, akan meningkatkan kesadaran wajib pajak.

13. Wajib pajak membayar pajak sesuai dengan jumlah pajak yang terutang.

14. Wajib pajak harus menpunyai pengetahuan mengenai peraturan perpajakan.

Self Assessment System (SAS) (Y)

Pada penelitian ini, variabel ini diukur dengan kuisioner skala likert 5 point untuk
13 pertanyaan. Berikut ini ringkasan definisi operasional Self Assessment System.

Tabel 3

Definisi Operasional Variabel Self Assessment System

\begin{tabular}{|c|c|c|c|}
\hline Variabel & Definisi Operasional & Indikator & Skala \\
\hline $\begin{array}{l}\text { Self } \\
\text { Assessment } \\
\text { System (Y) }\end{array}$ & $\begin{array}{l}\text { Self assessment system } \\
\text { merupakan suatu } \\
\text { pemungutan } \\
\text { pajak yang memberi } \\
\text { wewenang kepada } \\
\text { Wajib pajak untuk } \\
\text { menentukan pajak } \\
\text { terutang. Dalam hal ini } \\
\text { Wajib Pajak diberi } \\
\text { tanggung jawab untuk } \\
\text { melaksanakan } \\
\text { kewajibannya } \\
\text { dibidang perpajakan } \\
\text { (Tarjo, 2006) }\end{array}$ & $\begin{array}{l}\text { 1. Wajib pajak sebagai penghitung } \\
\text { jumlah pajak terutang. } \\
\text { 2. Fiskus tidak ikut campur dan hanya } \\
\text { mengawasi. } \\
\text { 3. SPT merupakan alat untuk } \\
\text { menghitung dan melaporkan jumlah } \\
\text { pajak terutang } \\
\text { 4. SPT merupakan alat untuk } \\
\text { melaporkan pajak dan perhitungan } \\
\text { pajak teutang. } \\
\text { Wajib pajak aktif mulai menghitung, } \\
\text { menyetor, melaporkan sendiri pajak } \\
\text { terutang. } \\
\text { Wajib pajak memiliki kemampuan } \\
\text { menghitung pajak yang terutang } \\
\text { dengan benar. } \\
\text { Wajib pajak tidak harus mempunyai } \\
\text { kemampuan untuk mengisi Surat } \\
\text { Pemberitahuan (SPT). }\end{array}$ & Ordinal \\
\hline
\end{tabular}


8. Pemberian Reward dan Punishment diperlukan guna meningkatkan kesadaran pembayaran perpajakan oleh wajib pajak.

9. Setiap wajib pajak mempunyai Nomor Pokok Wajib Pajak (NPWP)

10. Berhasil atau tidaknya pelaksanaan pemungutan pajak tergantung pada wajib pajak sendiri.

11. Semakin mudah proses pembayaran pajak, semakin tinggi tingkat kesadaran seseorang dalam membayar pajaknya.

12. sistem kontrol dapat dilakukan atau dilaksanakan dengan baik

13. Wajib pajak secara suka rela menghitung, menyetor, melaporkan sendiri pajak terutang.

\section{Pengembangan Instrumen Penelitian}

Dalam penelitian ini, peneliti menggunakan data kuantitatif dan menngunakan kuisioner untuk mengukur variabel independent dan varibel dependen. Di dalam kuisioner ini, peneliti menggunakan alat ukur yaitu skala likert 5 (lima) point. Skala likert merupakan metode skala bipolar yang mengukur baik tanggapan positif ataupun negatif terhadap suatu pernyataan. Empat skala pilihan juga kadang digunakan untuk kuesioner skala Likert yang memaksa orang memilih salah satu kutub karena pilihan "netral" tak tersedia (Wikipedia).

Penelitian ini menggunakan pilot test (uji awal) sebelum penelitian yang sebenarnya dilaksanakan. Kuisioner pilot test disebar sebanyak 30 responden yang terdiri dari mahasiswa Universitas Sarjanawiyata Tamansiswa dan mahasiswa Universitas lain yang tinggal disekitar tempat tinggal sementara peneliti.

\section{Populasi, Salmpel dan Teknik Pengambilan Sampel}

Dalam penelitian ini Populasi yang akan dijadikan sebagai obyek penelitian adalah Wajib Pajak Orang Pribadi yang berada di wilayah Bantul dan individu yang telah memiliki Nomor Pokok Wajib Pajak (NPWP). Teknik pengambilan sample penelitian dipakai yaitu simple random sampling technique terhadap 70 Wajib Pajak Orang Pribadi yang berada di wilayah Bantul dan individu yang telah memiliki Nomor Pokok Wajib Pajak (NPWP). Prosedur pengumpulan data yang digunakan dalam penelitian ini adalah dengan cara langsung menyampaikan pertanyaan yang berupa kuisioner dan wawancara langsung dengan Wajib Pajak Orang Pribadi di wilayah Bantul.

\section{Metode Analisis Data}

Jawaban responden diukur dengan menggunakan skala likert. Menurut Sugiono (2006) skala likert digunakan untuk mengukur sikap, pendapat, persepsi seseorang atau sekelompok orang tentang fenomena sosial. Teknik analisis data yang digunakan adalah software SPSS 16. Untuk item tertentu dilakukan pembalikan skor penilaian. Pengujian yang dipakai dalam analisis data penelitian ini adalah:

\section{Statistik Deskriptif}

Analisis statistik deskriptif digunakan untuk memberikan gambaran mengenai variabel yang diteliti. Uji statistik deskriptif mencakup nilai rata-rata (mean), nilai minimum, nilai maksimum, nilai mean, nilai range, nilai standar deviasi, dari data tingkat 
kepatuhan Wajib Pajak dan penerimaan pajak ( Widjaya, 2011).

\section{Uji Kualitas Data}

Uji kualitas data tersebut dilakukan dengan program SPSS 16.

\section{Uji Validitas}

Kesahihan (validity) suatu alat ukur adalah kemampuan alat ukur untuk mengukur indikator-indikator dari suatu objek pengukuran. Pengujian validitas dapat dilakukan dengan melihat nilai Correlated Item-Total Correlation dengan kriteria sebagai berikut: jika nilai $r$ hitung lebih besar dari $r$ tabel dan nilainya positif (pada taraf signifikan 5 persen atau 0,05), maka butir atau pertanyaan atau indikator tersebut dikatakan "valid", dan sebaliknya (Ghozali, 2006).

\section{Uji Reliabilitas}

Suatu kuesioner dikatakan reliable atau handal jika jawaban seseorang terhadap pertanyaan adalah konsisten atau stabil dari waktu ke waktu. Untuk itu perlu dilakukan uji reliabilitas. Pada umumnya suatu konstruk atau variabel dikatakan reliable jika memberikan nilai cronbach alpa lebih besar dari 0.60 (Ghozali, 2006).

\section{Uji Asumsi Klasik}

\section{Uji Normalitas}

Uji normalitas dilakukan untuk mengetahui apakah dalam model regresi, variabel-variabel memiliki distribusi normal. Probability Plot merupakan metode yang handal untuk menguji apakah dalam sebuah model regresi, variabel independen atau keduanya mempunyai distribusi normal atau tidak . Probability Plot adalah sebagai berikut. (Ghozali, 2006)

1. Jika data menyebar di sekitar garis diagonal dan atau tidak mengikuti arah garis diagonal, maka model regresi memenuhi asumsi normalitas.

2. Jika data menyebar jauh dari garis diagonal dan atau tidak mengikuti arah garis diagonal, maka model regresi tidak memenuhi asumsi normalitas.

\section{Multikolonieritas}

Uji multikolonieritas dilakukan dengan menganalisis matriks korelasi variabelvariabel independen, nilai Tolerance, dan nilai Variance Inflation Factor (VIF). Suatu model regresi menunjukkan adanya multikolinearitas jika: x Tingkat korelasi > $95 \%$ x Nilai Tolerance $<0.05$, atau $x$ Nilai VIF > 10. Model regresi yang baik seharusnya tidak terjadi korelasi antar variabel independen (Ghozali, 2006).

\section{Heterokedastisitas}

Model regresi yang baik adalah yang homoskedastisitas (Ghozali, 2006). Cara mendeteksi Heteroskedastisitas adalah dengan melihat grafik plot antara nilai prediksi variabel dependen dengan residualnya dan melihat ada tidaknya pola tertentu pada grafik scatterplot. Jika ada pola tertentu, seperti titik-titik yang ada membentuk suatu pola yang teratur (bergelombang, melebar, kemudian menyempit), maka mengindikasikan telah terjadi heteroskedastisitas. 


\section{Analisis Regresi Linier berganda}

Model regresi yang digunakan untuk menguji hipotesis adalah sebagai berikut:

$\mathrm{Y}=\mathrm{a}+\mathrm{b} 1 \mathrm{X} 1+\mathrm{b} 2 \mathrm{X} 2+\mathrm{e}$

Keterangan:

$\begin{array}{ll}\mathrm{Y} & =\text { self assessment system } \\ \mathrm{a} & =\text { Konstanta } \\ \mathrm{b} 1, \mathrm{~b} 2 & =\text { Koefisien regresi } \\ \mathrm{X} 1 & =\text { Pelayanan pajak } \\ \mathrm{X} 2 & =\text { Kepatuhan pajak } \\ \mathrm{e} & =\text { Error }\end{array}$

\section{Pengujian Hipotesis \\ Uji Parsial (Uji t)}

Uji $t$ dilakukan untuk mengetahui pengaruh masing-masing variabel independen secara partial (individu) tehadap variabel dependen. Tingkat kepercayaan yang digunakan adalah $95 \%$ atau taraf signifikansi 5\% ( $\mathrm{a}=0,05)$ dengan kriteria penilaian sebagai berikut: $\mathrm{t}$ hitung $>\mathrm{t}$ tabel, maka Ho ditolak dan Ha diterima yang berarti bahwa ada pengaruh yang signifikan dari masing-masing variabel independen terhadap variabel dependen secara parsial. $\mathrm{t}$ hitung < t tabel, maka Ho diterima dan Ha ditolak yang berarti bahwa tidak ada pengaruh yang signifikan dari masing-masing variabel independen terhadap variabel dependen secara parsial. $\mathrm{x}$ Uji Signifikansi

\section{Simultan (Uji Statistik F)}

Tingkat kepercayaan yang digunakan adalah 95\% atau taraf signifikansi 5\% $(\mathrm{a}=$ $0,05)$ dengan kriteria penilaian sebagai

\section{ANALISIS DAN PEMBAHASAN Gambaran Umum Objek Penelitian Tempat dan Waktu Penelitian}

Penelitian ini dilakukan terhadap wajib pajak orang pribadi yang terdaftar di Kantor Pajak Pratama Pratama Bantul. Penyebaran berikut: Jika $\mathrm{F}$ hitung > F tabel, maka Ho ditolak dan Ha diterima yang berarti bahwa variabel independen secara simultan mempunyai pengaruh yang signifikan terhadap variabel dependen; Jika $\mathrm{F}$ hitung < F tabel, maka Ho diterima dan Ha ditolak yang berarti bahwa variabel independen secara simultan tidak mempunyai pengaruh yang signifikan terhadap variabel dependen.

\section{Koefisien Determinasi}

Koefisien determinasi $\left(\mathrm{R}^{2}\right)$ pada intinya mengukur seberapa jauh kemampuan model dalam menerangkan variasi variabel independen. Nilai $\mathrm{R}$ yang kecil berarti kemampuan variabel-variabel independen dalam menjelaskan variasi variabel dependen sangat terbatas. Menurut Gujarati dalam Ghozali (2006), jika dalam uji empiris didapat nilai adjusted $\mathrm{R}^{2}$ negatif, maka nilai adjusted $R^{2}$ dianggap nol. Secara matematis jika nilai $\mathrm{R}^{2}=1$, maka $\quad \mathrm{R}^{2} \quad=1$, sedangkan jika nilai $\mathrm{R}^{2}=0$, maka adjusted $\mathrm{R}$ ${ }^{2}=(1-k) /(n-k)$. Jika $\mathrm{k}>1$, maka adjusted $\mathrm{R}^{2}$ akan bernilai negatif.

kuisioner dilaksanakan mulai tanggal 12 September 2013 sampai dengan 26 September 2013. Peneliti mengambil sampel sebanyak 70 responden (wajib pajak) dengan peta distribusi sebagai berikut.

Tabel 4

Data Sample Penelitian

\begin{tabular}{llll}
\hline No. & Keterangan & $\begin{array}{c}\text { Jumlah wajib pajak } \\
\text { orang pribadi }\end{array}$ & Persentase \\
\hline 1. & Jumlah kuisioner yang disebar & 70 buah & $100 \%$ \\
2. & Jumlah kuisioner yang kembali & 60 buah & $85.72 \%$
\end{tabular}




\section{JURNAL AKUNTANSI. VOL.2 NO.1 JUNI 2014}

3. Jumlah kuisioner yang tidak sah

7 buah

$10 \%$

4. Jumlah kuisioner yang tidak kembali

3 buah

$4,28 \%$

5. Jumlah kuisioner yang diolah

60 buah

$100 \%$

Tabel 5

Hasil Uji Deskripsi Responden Menurut Umur

\begin{tabular}{llllcr}
\hline & & & & \multicolumn{2}{c}{ Cumulative } \\
\hline Valid & $<30$ tahun & 27 & 45.0 & 45.0 & 45.0 \\
& $31-40$ tahun & 21 & 35.0 & 35.0 & 80.0 \\
& $41-50$ tahun & 12 & 20.0 & 20.0 & 100.0 \\
& Total & 60 & 100.0 & 100.0 & \\
\hline
\end{tabular}

Tabel 6

Hasil Uji Deskripsi Responden Menurut Jenis Kelamin

\begin{tabular}{llllcr}
\hline & & & & \multicolumn{2}{c}{ Cumulative } \\
& & Frequency & Percent & Valid Percent & Percent \\
\hline Valid & laki-laki & 34 & 56.7 & 56.7 & 56.7 \\
& perempuan & 26 & 43.3 & 43.3 & 100.0 \\
& Total & 60 & 100.0 & 100.0 & \\
\hline
\end{tabular}

Tabel 7

Hasil Uji Deskripsi Responden Menurut Pendidikan Terakhir

\begin{tabular}{|c|c|c|c|c|c|}
\hline & & Frequency & Percent & Valid Percent & $\begin{array}{l}\text { Cumulative } \\
\text { Percent }\end{array}$ \\
\hline \multirow[t]{6}{*}{ Valid } & SD & 5 & 8.3 & 8.3 & 8.3 \\
\hline & SMP & 9 & 15.0 & 15.0 & 23.3 \\
\hline & SMA & 21 & 35.0 & 35.0 & 58.3 \\
\hline & S1 & 17 & 28.3 & 28.3 & 86.7 \\
\hline & Lainnya & 8 & 13.3 & 13.3 & 100.0 \\
\hline & Total & 60 & 100.0 & 100.0 & \\
\hline \multicolumn{6}{|c|}{ Hasil Uji Deskripsi Responden Menurut Lama Bekerja } \\
\hline & & & Domont & Valid Percent & Cumulative \\
\hline \multirow{6}{*}{ Valid } & $<2$ tahun & 8 & 13.3 & 13.3 & 13.3 \\
\hline & 2-4 tahun & 20 & 33.3 & 33.3 & 46.7 \\
\hline & 4-6 tahun & 16 & 26.7 & 26.7 & 73.3 \\
\hline & $6-8$ tahun & 10 & 16.7 & 16.7 & 90.0 \\
\hline & $>8$ tahun & 6 & 10.0 & 10.0 & 100.0 \\
\hline & Total & 60 & 100.0 & 100.0 & \\
\hline
\end{tabular}

Tabel 9

Hasil Uji Deskripsi Responden Menurut Penghasilan per Bulan 


\begin{tabular}{|c|c|c|c|c|c|}
\hline & & Frequency & Percent & $\begin{array}{l}\text { Valid } \\
\text { Percent }\end{array}$ & $\begin{array}{l}\text { Cumulative } \\
\text { Percent }\end{array}$ \\
\hline \multirow[t]{5}{*}{ Valid } & $<\mathrm{Rp} 5.000 .000$ & 27 & 45.0 & 45.0 & 45.0 \\
\hline & Rp 5.000.000 - Rp 10.000.000 & 18 & 30.0 & 30.0 & 75.0 \\
\hline & $\begin{array}{l}\text { Rp 10.000.000 - Rp } \\
15.000 .000\end{array}$ & 13 & 21.7 & 21.7 & 96.7 \\
\hline & $\begin{array}{l}\text { Rp 15.000.000 - Rp } \\
20.000 .000\end{array}$ & 2 & 3.3 & 3.3 & 100.0 \\
\hline & Total & 60 & 100.0 & 100.0 & \\
\hline
\end{tabular}

\section{Hasil Uji Instrumen Penelitian Hasil Uji Statistik Deskriptif}

Tabel 10

Hasil Uji Statistik Deskripsi

\begin{tabular}{lllrlr}
\hline & $\mathrm{N}$ & Minimum & Maximum & Mean & Std. Deviation \\
\hline PELAYANAN & 60 & 30.00 & 43.00 & 37.0333 & 3.04189 \\
KEPATUHAN & 60 & 45.00 & 65.00 & 59.4500 & 3.81533 \\
SAS & 60 & 45.00 & 62.00 & 51.3667 & 3.90552 \\
Valid N (listwise) & 60 & & & & \\
\hline
\end{tabular}

Tabel 10 menjelaskan bahwa sistem pelayanan pajak dengan rata-rata total sebesar 37, 033, dengan standar deviasi sebesar 3.04189. Ini berarti bahwa sebagian responden cenderung menjawab setuju untuk pertanyaan yang diajukan berkaitan dengan masalah sistem pelayanan wajib pajak. Variabel kepatuhan wajib pajak dengan ratarata total 59,450 dengan standar deviasi sebesar 3.81533 menunjukkan bahwa tingkat kepatuhan wajib pajak menjadi responden dalam penelitian ini sebesar $59 \%$. Ini berarti bahwa sebagian responden menjawab setuju dalam hal kepatuhan wajib pajak orang pribadi. Variabel penerapan self assessment system dengan rata-rata total sebesar 51,367 dengan standar deviasi sebesar 3.90552 menunjukkan bahwa tingkat penerapan self assessment system dalam penelitian ini sebesar $51 \%$. Ini berarti sebagian responden menjawab setuju untuk pertanyaan yang diajukan berkaitan dengan penerapan self assessment system . Nilai standar deviasi masing-masing variabel lebih kecil dari nilai rata-rata maka data yang diperoleh dari lapangan dapat direpresetasikan ke populasi.

\section{Hasil Uji Kualitas Data Hasil Uji Validitas Data}

Tabel 11

Hasil Pengujian Validitas

\begin{tabular}{|c|c|c|c|c|c|}
\hline No & Variabel / Butir Pertanyaan & Pearson & \multicolumn{2}{|c|}{ Sig (2-Tailed) } & Keterangan \\
\hline \multirow[t]{6}{*}{1} & Pelayanan pajak & & & & \\
\hline & VAR00001 & & $.393^{* *}$ & .002 & Valid \\
\hline & VAR00002 & & $.268^{*}$ & .038 & Valid \\
\hline & VAR00003 & & $.419^{* *}$ & .001 & Valid \\
\hline & VAR00004 & & $.474^{* *}$ & .000 & Valid \\
\hline & VAR00005 & & $.393^{* *}$ & .002 & Valid \\
\hline
\end{tabular}


JURNAL AKUNTANSI. VOL.2 NO.1 JUNI 2014

\begin{tabular}{|c|c|c|c|c|c|}
\hline & VAR00006 & & $.268^{*}$ & .038 & Valid \\
\hline & VAR00007 & & $.776^{* *}$ & .000 & Valid \\
\hline & VAR00008 & & $.474^{* *}$ & .000 & Valid \\
\hline & VAR00009 & & $.657^{* *}$ & .000 & Valid \\
\hline 2 & Kepatuhan & & & & \\
\hline & VAR00001 & & $.357^{* *}$ & .005 & Valid \\
\hline & VAR00002 & & $.515^{* *}$ & .000 & Valid \\
\hline & VAR00003 & & $.290^{*}$ & .025 & Valid \\
\hline & VAR00004 & & $.467^{* *}$ & .000 & Valid \\
\hline & VAR00005 & & $.357^{* *}$ & .005 & Valid \\
\hline & VAR00006 & & $.482^{* *}$ & .000 & Valid \\
\hline & VAR00007 & & $.545^{* *}$ & .000 & Valid \\
\hline & VAR00008 & & $.485^{* *}$ & .000 & Valid \\
\hline & VAR00009 & & $.467^{* *}$ & .000 & Valid \\
\hline & VAR00010 & & $.299^{*}$ & .020 & Valid \\
\hline & VAR00011 & & $.545^{* *}$ & .000 & Valid \\
\hline & VAR00012 & & $.331^{* *}$ & .010 & Valid \\
\hline & VAR00013 & & $.543^{* *}$ & .000 & Valid \\
\hline & VAR00014 & & $.576^{* *}$ & .000 & Valid \\
\hline 3 & Self Assessn & t System & & & \\
\hline & VAR00001 & & $.572^{* *}$ & .000 & Valid \\
\hline & VAR00002 & & $.594^{* *}$ & .000 & Valid \\
\hline & VAR00003 & & $.423^{* *}$ & .001 & Valid \\
\hline & VAR00004 & & $.293^{*}$ & .023 & Valid \\
\hline & VAR00005 & & $.745^{* *}$ & .000 & Valid \\
\hline & VAR00006 & & $.520^{* * *}$ & .000 & Valid \\
\hline & VAR00007 & & $.293^{*}$ & .023 & Valid \\
\hline & VAR00008 & & $.594^{* *}$ & .000 & Valid \\
\hline & 0009 & $.745^{* *}$ & .000 & Valid & \\
\hline & 0010 & $.520^{* *}$ & .000 & Valid & \\
\hline & 0011 & $.572^{* *}$ & .000 & Valid & \\
\hline & 0012 & $.293^{*}$ & .023 & Valid & \\
\hline & 0013 & $.594^{* *}$ & .000 & Valid & \\
\hline
\end{tabular}

a. Hasil Uji Reliabilitas Data 
Tabel 12

Hasil Pengujian reliabilitas

\begin{tabular}{lcc}
\hline Variabel & Cronbach Alpha & Keterangan \\
\hline Pelayanan pajak & .661 & Reliabel \\
Kepatuhan & .732 & Reliabel \\
Self Assessment System & .863 & Reliabel \\
\hline
\end{tabular}

Tabel 12 menunjukkan mengenai uji reliabilitas dimana suatu instrumen cukup dapat dipercaya untuk digunakan sebagai alat pengumpulan data karena instrumen sudah baik atau suatu angket dikatakan reliabel jika jawaban responden konsisten. Pada umumnya suatu konstruk atau variabel dikatakan reliable jika memberikan nilai cronbach alpa lebih besar dari 0.60 (Ghozali, 2006). Kolom Cronbach Alpha menunjukkan lebih besar dari 0,60, maka instrumen ini dapat dipercaya untuk digunakan sebagai alat pengumpulan data.

\section{Hasil Uji Asumsi Klasik Hasil Uji Normalitas}

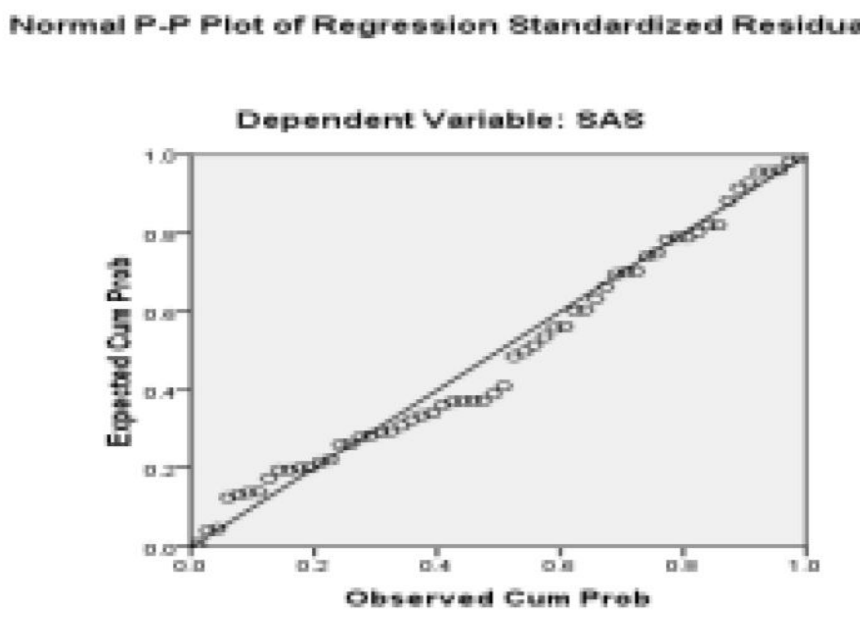

\section{Hasil Uji Multikolonieritas}

Tabel 4.10 ini menjelaskan mengenai hasil uji multikolonieritas, dimana tidak terdapat problem multikol pada model persamaan regresi dan dapat digunakan dalam penelitian ini.

Tabel 13

Hasil Uji Multikolonieritas

\begin{tabular}{cccc}
\hline Model & Collinearity Statistics & Tolerance & VIF \\
\hline \multirow{2}{*}{1} & PELAYANAN & .975 & 1.026 \\
& KEPATUHAN & .975 & 1.026 \\
\hline
\end{tabular}

a. Dependent Variable: SAS 
Berdasarkan tabel di atas terlihat bahwa nilai tolerance menunjukkan angka 1 dan nilai variance inflatuion factor (VIF) disekitar angka 1 untuk setiap variabel, yang ditunjukkan dengan nilai tolerance masingmasing variabel 0,975 serta VIF sebesar
1,026 untuk masing-masing variabel, baik variabel kepatuhan wajib pajak orang pribadi maupun variabel sistem pelayanan pajak. Hal ini dapat disimpulkan bahwa tidak terjadi multikolonieritas dalam persamaan regresi berganda.

\section{Hasil Uji Heteroskedastisitas}

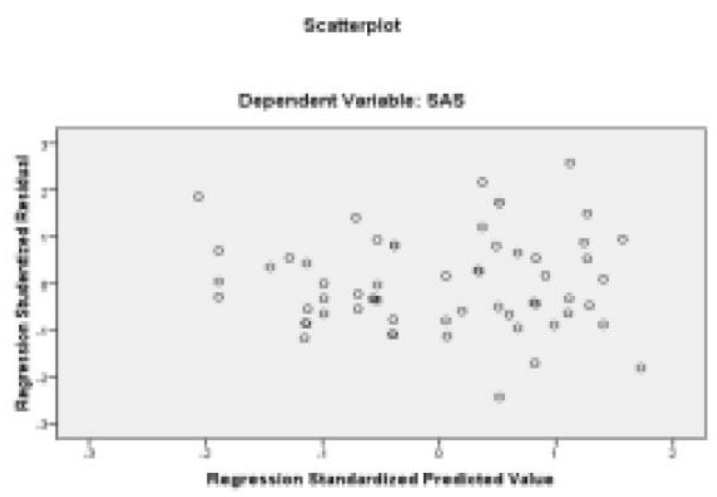

Grafik 4.2

Hasil Uji Heteroskedastisitas

Berdasarkan gambar di atas layak digunakan untuk memprediksi menunjukkan bahwa data tersebar di atas dan penerapan self assessment system di bawah angka 0 (nol) pada sumbu $\mathrm{Y}$ dan berdasarkan variabel yang tidak terdapat suatu pola yang jelas pada mempengaruhinya, yaitu sistem pelayanan penyebaran tersebut. Hal ini berarti tidak pajak dan kepatuhan wajib pajak orang terjadi heteroskedastisitas pada model pribadi. persamaan regresi, sehingga model regresi

\section{Hasil Uji Hipotesis \\ Uji Koefisien Determinasi}

Tabel 14

Hasil Uji Koefisien Determinasi

\begin{tabular}{lcccc}
\hline Model & $\mathrm{R}$ & $\mathrm{R}$ Square & Adjusted R Square & $\begin{array}{c}\text { Std. Error of the } \\
\text { Estimate }\end{array}$ \\
\hline 1 & $.608^{\mathrm{a}}$ & .370 & 348 \\
3.15327 & & & \\
\hline $\begin{array}{l}\text { a. Predictors: (Constant), KEPATUHAN, PELAY ANAN } \\
\text { b. Dependent Variable: SAS }\end{array}$
\end{tabular}

Tabel di atas menunjukkan bahwa nilai Adjusted R Square sebesar 0,348 atau 34,8\% menunjukkan bahwa variabel self assessment system dapat dijelaskan oleh sistem pelayanan pajak dan kepatuhan wajib pajak orang pribadi sebesar $34,8 \%$ sedangkan sisanya sebedar $65,2 \%$ dijelaskan oleh faktor-faktor lain yang tidak disebutkan dalam penelitian ini.

Hasil Uji t Statistik 
Tabel 15

Hasil Uji T Statistik

\begin{tabular}{lllllll}
\hline \multirow{2}{*}{ Model } & \multicolumn{7}{c}{ Standardized } \\
& \multicolumn{7}{c}{ Unstandardized Coefficients Coefficients } & T & Sig. \\
& B $\quad$ Std. Error & Beta & & \\
\hline $1 \quad$ Constant) & 45.455 & 7.576 & & 6.000 & .000 \\
PELAYANAN & \multicolumn{2}{c}{.720} & .137 & .561 & 5.267 & .000 \\
KEPATUHAN & & -.349 & .109 & -.341 & -3.203 & .002 \\
\hline
\end{tabular}

a. Dependent Variable: SAS

\begin{abstract}
Hasil Uji Hipotesis 1:
Pengaruh sistem pelayanan pajak terhadap penerapan self assessment system

Berdasarkan tabel di atas, dapat dilihat bahwa nilai t hitung untuk variabel sistem pelayanan pajak (X1) terhadap penerapan self assessment system (Y) sebesar 5,267, berarti $\mathrm{t}$ hitung $>\mathrm{t}$ tabel $(5,267>2,01)$, memiliki tingkat signifikansi 0,000 karena tingkat signifikansi lebih kecil dari 0,05. Hal ini membuktikan bahwa $\mathrm{H} 0$ ditolak dan $\mathrm{Ha}$ diterima, ini menunjukkan bahwa variabel sistem pelayanan pajak berpengaruh positif signifikan terhadap penerapan self assessment system.
\end{abstract}

\section{Hasil Uji Hipotesis 2:}

Pengaruh kepatuhan wajib pajak orang pribadi terhadap penerapan self assessment system

Hasil pengujian variabel kepatuhan wajib pajak orang pribadi (X2) terhadap penerapan self assessment system (Y) sebesar

3,203 , berarti $\mathrm{t}$ hitung $<\mathrm{t}$ tabel $(-3,203<$ 2,01), memiliki tingkat signifikansi 0,000 karena tingkat signifikansi lebih kecil dari 0,05, hal ini membuktikan bahwa H0 diterima dan Ha ditolak, ini menunjukkan bahwa variabel kepatuhan wajib pajak orang pribadi berpengaruh signifikan terhadap penerapan self assessment system Berdasarkan tabel di atas, maka diperoleh persamaan regresi sebagai berikut.

$\mathrm{Y}=45.455+0,720 \mathrm{X} 1-0.349 \mathrm{X} 2+\mathrm{e}$

Apabila setiap peningkatan pada sistem pelayanan pajak (X1) satu satuan maka penerapan self assessment system akan meningkat sebesar 0,720, kemudian setiap peningkatan pada kepatuhan wajib pajak orang pribadi akan mengurangi sebesar 0,349 .

\section{Hasil Uji Simultan (Uji F)}

Uji simultan digunakan untuk mengetahui pengaruh semua variabel independen yang dimasukkan dalam model regresi secara simultan terhadap variabel dependen yang diuji pada tingkat signifikan 0,05 . Hasil uji statistik $F$ dapat dilihat pada tabel berikut.

Tabel 16

Hasil Uji Simultan (uji F) ANOVA $^{\text {b }}$

\begin{tabular}{llccccc}
\hline Model & & Sum of Squares & Df & Mean Square & F & Sig. \\
\hline 1 & Regression & 333.176 & 2 & 166.588 & 16.754 & $.000^{\mathrm{a}}$ \\
& Residual & 566.757 & 57 & 9.943 & & \\
& Total & 899.933 & 59 & & & \\
\hline
\end{tabular}

a. Predictors: (Constant), KEPATUHAN, PELAYANAN, b. Dependent Variable: SAS 
Hasil Uji Hipotesis 3:

Pengaruh sistem pelayanan pajak dan kepatuhan wajib pajak orang pribadi terhadap penerapan self assessment system

Hasil uji hipotesis 3 dapat dilihat pada tabel di atas, nilai F diperoleh sebesar 16,754 dengan tingkat kesalahan 5\%, dimana $\mathrm{dk}$ penyebut $=\mathrm{n}-\mathrm{k}-1=60-2-1=57, \mathrm{dk}$ pembilang $=\mathrm{k}=2$, maka $\mathrm{F}$ tabel $=2,82$ tenyata $\mathrm{F}$ hitung $>\mathrm{F}$ tabel $(16,754>2,82)$, dengan demikian $\mathrm{F}$ hitung $>\mathrm{F}$ tabel sehingga H0 ditolak dan Ha diterima, ini meunjukkan bahwa secara simultan antara sistem pelayanan pajak dan kepatuhan wajib pajak orang pribadi berpengaruh terhadap penerapan self assessment system.

\section{Simpulan}

Berdasarkan analisis data dan hasil pengujian hipotesis pada penelitian ini dapat disimpulkan bahwa sistem pelayanan pajak berpengaruh positif signifikan terhadap penerapan Self Assessment System sedangkan kepatuhan wajib pajak orang pribadi berpengaruh negatif signifikan terhadap penerapan Self Assessment System. Kemampuan persamaan regresi dalam penelitian ini, untuk menjelaskan besarnya variasi yang terjadi pada variabel terikat sebesar $34,8 \%$ sementara 65,2\% dijelaskan oleh variabel lain yang tidak dijelaskan oleh peneliti.

\section{Keterbatasan}

Berdasarkan kesimpulan dari hasil penetian ini, peneliti memiliki keterbatasan antara lain:

1. Penelitian hanya dilakukan di Kantor Pelayanan Pajak Pratama Bantul, sehingga hasil penelitian ini hanya mencerminkan persepsi wajib pajak pada satu Kantor Pelayanan Pajak.

2. Penelitian ini hanya menggunakan metode pengumpulan data berupa kuisioner yang disebarkan untuk diisi oleh responden. Sedangkan respon dari responden untuk mengisi kuisioner kurang begitu antusias.

\section{Saran}

Untuk selanjutnya, peneliti mengajukan saran sebagai berikut:

1. Perlunya sosialiasasi kepada masyarakat khususnya wajib pajak tentang peraturan perpajakan yang berlaku saat ini dan pentingnya pajak bagi negara dalam rangka meningkatkan pengetahuan wajib pajak dan meningkatkan penerimaan pajak negara guna pembiayaan keperluan negara.

2. Memberikan kemudahan bagi wajib pajak dalam sarana maupun prasarana dalam memenuhi kewajibannya membayar pajak.

3. Petugas pajak perlu meningkatkan kualitas pelayanan pajak serta mempunyai mental yang kuat dalam melayani wajb pajak dengan sebaikbaiknya.

4. Penelitian selanjutnya dapat dilakukan di Kantor Pelayanan Pajak lainnya.

\section{DAFTAR PUSTAKA}

Apriliani, Ria. ."Pengaruh Penerapan

Sistem Modernisasi Administrasi

Perpajakan Terhadap Kepatuhan

Wajib Pajak

Boediono, B. 2003. Pelayanan Prima

Perpajakan. PT. Rineka Cipta. Jakarta.

Budileksama, Antariksa. 2001.

Pemeriksaan Pajak Sebagai Upaya

Untuk Mendorong Kepatuhan Pajak.

Jurnal Akuntansi dan Investasi Vol. 2

No. 1. Universitas Trisakti. Jakarta.

Chakim, Lutfi. 2011. Optimalisasi Kualitas

Pelayanan Sebagai Upaya

Peningkatan Kepatuhan Wajib Pajak

Secara Sukarela (Voluntary

Compliance).

Damayanti, T.W,. 2004. Pelaksanaan Self

Assesment System menurut Persepsi

Wajib Pajak (Studi pada Wajib Pajak

Badan Salatiga), Jurnal Ekonomi dan

Bisnis (Dian Ekonomi) vol. X No. 1,

Maret 2004: 109-128.

Devano, Sony dan Siti Kurnia Rahayu. 2006.

Perpajakan. Prenada Media Group.

Jakarta. 
Erief. 2007. A Multiple Item Scale for Measuring Consumer Perception of Services Quality.

Journal of Retailing. Vol. 64, Spring, p. 1240.

Fitriandi, Primadita. 2007. Kompilasi Undang-Undang Perpajakan Terlengkap Susunan Satu naskah. Salemba Empat.

Fuadi, Arrabela Oentari dan Yenni Mangoting. 2013. Pengaruh Kualitas Pelayanan Petugas Pajak, Sanksi Perpajakan dan Biaya Kepatuhan Pajak Terhadap Kepatuhan Wajib Pajak UMKM. Tax \& Accounting Review. Vol 1, No.1.

Ghozali, Imam. 2005. Aplikasi Analisis Multivariate dengan Program SPSS . Edisi Ketiga. Badan Penerbit UNDIP. Semarang.

Gunadi. 2002. Ketentuan Perhitungan dan

Pelunasan Pajak Penghasilan. Cetakan Pertama. Salemba Empat. Jakarta. 2005. Fungsi Pemeriksaan

Terhadap Peningkatan Kepatuhan Pajak ( Tax Compliance). Jurnal Perpajakan Indonesia Vol. 4 no. 5. Hutagaol, John. 2005. "Self Assessment: Implementasi dan Kendalanya " . Jurnal Perpajakan Indonesia. LIPI. Jakarta.

Ismawan, Indra. 2001. Memahami Reformasi Perpajakan 2000. PT. Elex Media Koputindo. Jakarta.

Kamus Besar Bahasa Indonesia

Kartowagiran, Badrun. 2009. Pengembangan Instrumen Kinerja SMK-SBI. Dosen Pascasarjana dan Fakultas Teknik. Universitas Negeri Yogyakarta.

Keputusan Menteri Pemberdayaan Aparatur Negara (KEPMENPAN) Nomor 63

Tahun 2003 tentang Pedoman Umum Pelayanan Publik.

Kesit, Bambang. 2001. Pajak

Penghasilan Teknik Rekonsiliasi

Fiskal. Edisi Kedua.

Ekonisia.Yogyakarta.

Mardiasmo. 2009. Perpajakan. Yogyakarta: Penerbit Andi.
Nasucha, Chaizi. 2004. Reformasi Administrasi Publik : Teori dan Praktik . Jakarta: PT. Gramedia Widiasarana Indonesia.

Novianti, L. (1997). Penerapan System Self Assessment Terhadap Pemungutan PPh Orang Pribadi, Suatu Tinjauan Pelaksanaan Pemungutan PPh Orang Pribadi Pada Pemilik Rumah Kost. Skripsi Fakultas Hukum UNAIR Surabaya.

Oktivani, Debby. 2007. “ Pengaruh Kepatuhan Wajib Pajak dan Jumlah Pemeriksaan terhadap Penerimaan Pajak Penghasilan di Kantor Pelayanan Pajak $M$ adiun." Skripsi Sarjana Jurusan Akuntansi Fakultas Ekonomi Universitas Kristen Petra, Surabaya.

Pramastuti, Ratih. 2003. Presepsi Wajib Pajak Terhadap Pemeriksaan Pajak Penghasilan Perorangan di Kantor Pelayanan Pajak X. Skripsi Fakultas Ekonomi dan Bisnis. UNAIR. Surabaya.

Rahmatika, Mufti. 2010. Analisis FaktorFaktor yang Berpengaruh Terhadap Kesadaran Kewajiban Perpajakan pada Sektor Usaha Kecil dan Menengah (UKM). Skripsi. Fakultas Ekonomi. UIN. Jakarta.

Rangkuti,Freddy. 2003. Riset Pemasaran.Gramedia Pustaka

Resmi, Siti. 2007. Perpajakan: Teori dan kasus. Salemba Empat. Jakarta

Sadhani, D. 2004. "Peran Serta Akuntan dalam Meningkatkan Kepatuhan wajib

Makalah disampaikan pada Kongres Nasional Ikatan Akuntan Indonesia V. Yogyakarta.

Santi, Anisa Nirmala dan Zulaikhah. 2011. Analisis Pengaruh Kesadaran Perpajakan, Sikap Rasional, Lingkungan, Sanksi Denda dan Sikap Fiskus Terhadap Kepatuhan Wajib Pajak (Studi Empiris Pada WPOP di Wilayah KPP Pratama Semarang). Semarang. 
Soemitro, Rochmat. 2004. Asas dan Dasar Perpajakan 2. PT. Repika Aditama. Bandung.

Sofyan, S. 2003. Sistem Penetapan Pajak (Dalam Kerangka Mencari Sistem Yang Kondusif). Jurnal Perpajakan Indonesia. Vol 3, Hal 28-34.

Suandy, Erly. 2002. Hukum Pajak. Edisi Kedua. Salemba Empat. Jakarta.

Sugiyono. 2006. Metode Penelitian Bisnis. Alfabeta. Bandung.

Suyatmin. 2004. Pengaruh Sikap Wajib

Pajak Terhadap Kepatuhan Wajib

Pajak Dalam Pembayaran Pajak

Bumi dan Bangunan: Studi

Empiris di Wilayah KP PBB

Surakarta. Tesis Program Pasca

Sarjana Magister Sains Akuntansi

Universitas Diponegoro.

Swandari. Handayani. 2007. Pelaksanaan

Self Assessment System Dalam

Pemungutan Bea Perolehan

Hak Atas Tanah dan Bangunan
(BPHTB) di Kab. Boyolali. UNDIP. Semarang.

Tarjo \& Kusumawati, Indra. 2006. Analisis Perilaku Wajib Pajak Orang Pribadi Terhadap Pelaksanaan Self Assessment System: Suatu Studi di Bangkalan. JAAI VOLUME 10 NO. 1. Fakultas Ekonomi Universitas Trunojoyo. Madura.

Waluyo dan Wirawan B. Ilyas. 2009. "Perpajakan Indonesia". Salemba Empat. Jakarta.

Widjaya, Anisa Gama. 2011. Studi Evaluasi Kepatuhan Pajak Sebelum dan Sesudah Reformasi Perpajakan 2008 dan Implementasinya terhadap Penerimaan Pajak pada KPP Pratama Kota Semarang Kantor Wilayah Direktorat Jendral Pajak Jawa Tengah I. UNDIP. Semarang.

Zain, M. 2003. Manajemen Perpajakan. PT. Salemba Empat. Jakarta.

http://id.wikipedia.org/wiki/Skala_Likert www.fiskal.depkeu.go.id 